\title{
Carotenemia induced by iron deficiency
}

\author{
Futoshi Nakagami @i) ,' Yoichi Nozato, ${ }^{2}$ Koichi Yamamoto, ${ }^{1}$ Hiromi Rakugi ${ }^{2}$
}

${ }^{1}$ General Internal Medicine, Osaka University Hospital, Suita, Osaka, Japan

${ }^{2}$ Geriatric Medicine, Osaka University Hospital, Suita, Osaka Japan

\section{Correspondence to}

Dr Futoshi Nakagami;

fnakagami@hp-gm.med.osakau.ac.jp

Accepted 18 September 2020

\section{DESCRIPTION}

A 56-year-old Chinese woman presented to the department of general internal medicine of our hospital with a 3-week history of general fatigue. According to her daughter's remark, she has looked unwell for 1 year and has been suffering from menstrual pain and hypermenorrhea due to a giant uterine myoma for 20 years. She denied hot flash, chill and night sweat as menopausal symptoms. Her skin of whole body was extremely yellow (figure 1), however her sclera was not icteric. And her conjunctiva was anaemic. Blood test revealed microcytic anaemia with iron deficiency (haemoglobin: $69 \mathrm{~g} / \mathrm{L}$, Mean Corpuscular Volume: 63\%, ferritin: $2 \mathrm{mg} / \mathrm{mL}$ ). Abnormal findings were not detected in bilirubin $(0.6 \mathrm{mg} / \mathrm{mL})$, glucose $(106$ $\mathrm{mg} / \mathrm{dL})$, creatinine $(0.69 \mathrm{mg} / \mathrm{dL})$, Thyroid Stimulating Hormone $(1.99 \mu \mathrm{IU} / \mathrm{mL})$ and F-T4 $(1.0 \mathrm{ng} / \mathrm{dL})$. Detailed history revealed that she has been eating four uncooked carrots and 20 mint candies per day for 3 months. Thus, she was diagnosed with carotenemia due to pica, which made her eat excessive carrots and mint candies. Pica was elicited by iron deficiency. And iron deficiency is suggested to be induced by hypermenorrhea related with the giant uterine myoma. We administered ferric oxide and her compulsion to eat carrots and mint candies disappeared in 3 days, before the improvement of anaemia.

Pica is one of the eating disorders characterised by compulsive ingestion of various substances including inedible things. The word pica is derived from the Latin for the bird magpie, which gleans various objects for its nest. Pica can be specified depending on the ingested substance, for example, pagophagia for ice, amylophagia for starch, cautopyreiophagia for burned matchsticks and geophagia for clay. ${ }^{1}$ Pica may occur in half of the iron deficient patients. ${ }^{2}$ Iron administration rapidly reduces cravings due to the pica, usually before the haematological parameter improvement.

Carotenemia is a medical condition characterised by xanthoderma which represent yellow-orange skin pigmentation. It is mainly induced by the excessive ingestion of food containing carotene, for example, oranges, apricots, mango, carrots and pumpkins. ${ }^{3}$ However, some conditions such as diabetes, hypothyroidism or kidney disease can induce carotenemia. The

Check for updates

(c) BMJ Publishing Group

Limited 2021. No commercial re-use. See rights and permissions. Published by BMJ.

To cite: Nakagami F, Nozato Y, Yamamoto $\mathrm{K}$ et al. BMJ Case Rep

2021:14:e236597.

doi:10.1136/bcr-2020-

236597
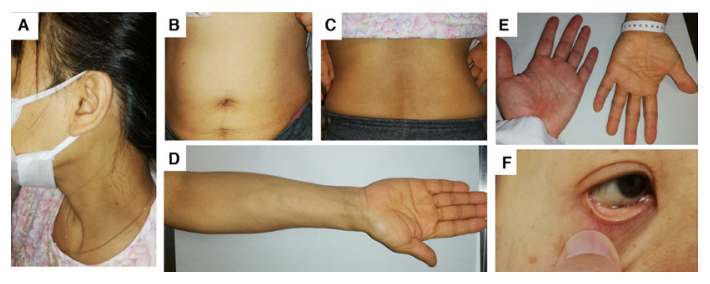

Figure 1 (A-D) Yellow skin of whole body. (E) Comparison of patient and author's skin (author is also mongoloid). (F) Normal sclera and anaemic conjunctiva.

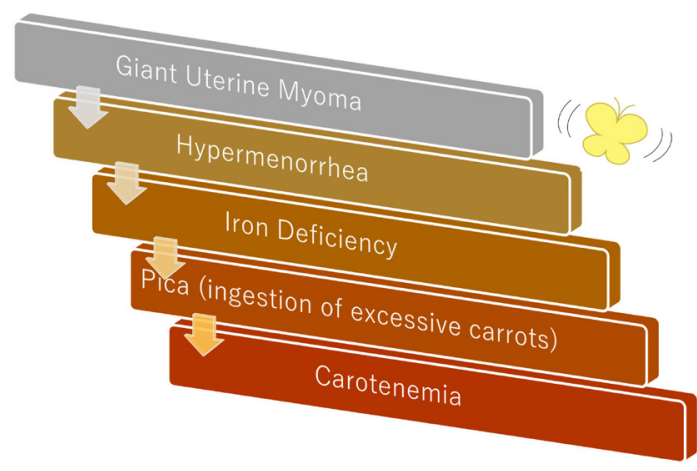

Figure 2 'Butterfly effect'; induced carotenemia due to giant uterine myoma.

Learning points

- Carotenemia should be differentiated from jaundice by obtaining appropriate physical examination and detailed patients' history.

- Carotenemia can be induced by pica due to the iron deficiency.

differential diagnosis of jaundice, detailed history and specific physical examination are the key to a definitive diagnosis. Skin pigmentation usually is prominent on the palms, soles, forehead and nasolabial folds. Compared with the jaundice, the sclera and mucous membranes are intact.

In this case, the assumed aetiology was the 'butterfly effect' of the giant uterine myoma eventually inducing carotenemia, which seemed to have no association (figure 2).

Physicians should consider that the yellow-orange skin pigmentation is not only observable in the case of jaundice but also in the case of carotenemia, which can be induced by pica due to the iron deficiency.

Contributors $\mathrm{YN}$ and $\mathrm{KY}$ contributed to the conception of the work and reporting. HR contributed to the reporting. YN, KY and HR approved the final version submitted and agreed to be accountable for all aspects.

Funding The authors have not declared a specific grant for this research from any funding agency in the public, commercial or not-for-profit sectors.

Competing interests None declared.

Patient consent for publication Obtained.

Provenance and peer review Not commissioned; externally peer reviewed.

ORCID iD

Futoshi Nakagami http://orcid.org/0000-0002-4144-7306

\section{REFERENCES}

1 Moore DF, Sears DA. Pica, iron deficiency, and the medical history. Am J Med 1994;97:390-3.

2 CrosbyWH. Pica. JAMA 1976;235:2765. 


\section{Images in...}

3 Al Nasser Y, Albugeaey M. Carotenemia.[Updated 2019 Dec 6]. In: StatPearls [Internet]. Treasure Island (FL): StatPearls Publishing, 2020. Available: https://uwww.ncbinlm.nih.gov/

Copyright 2021 BMJ Publishing Group. All rights reserved. For permission to reuse any of this content visit

https://www.bmj.com/company/products-services/rights-and-licensing/permissions/

BMJ Case Report Fellows may re-use this article for personal use and teaching without any further permission.

Become a Fellow of BMJ Case Reports today and you can:

- Submit as many cases as you like

- Enjoy fast sympathetic peer review and rapid publication of accepted articles

Access all the published articles

Re-use any of the published material for personal use and teaching without further permission

Customer Service

If you have any further queries about your subscription, please contact our customer services team on +44 (0) 2071111105 or via email at support@bmj.com.

Visit casereports.bmj.com for more articles like this and to become a Fellow 